NASA/TM-1999-209284

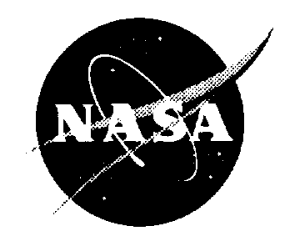

\title{
Comparison of the Tensile, Creep, and Rupture Strength Properties of Stoichiometric SiC Fibers
}

H.M. Yun

Cleveland State University, Cleveland, Ohio

J.A. DiCarlo

Glenn Research Center, Cleveland, Ohio

Prepared for the

23rd Annual Cocoa Beach Conference sponsored by the American Ceramic Society

Cocoa Beach, Florida, January 25-29, 1999

National Aeronautics and

Space Administration

Glenn Research Center 


\section{Acknowledgments}

We thank Dr. D. Bryd for the AES measurement, Dr. Y.L. Chen for the TEM studies, and Mr. T. Kacik for the TGA analyses.

Trade names or manufacturers' names are used in this report for identification only. This usage does not constitute an official endorsement, either expressed or implied, by the National Aeronautics and Space Administration.

Available from

NASA Center for Aerospace Information 7121 Standard Drive

Hanover, MD 21076

Price Code: A03
National Technical Information Service 5285 Port Royal Road Springfield, VA 22100 Price Code: A03 


\title{
Comparison of the Tensile, Creep, and Rupture Strength Properties of Stoichiometric SiC Fibers
}

\author{
H.M. Yun \\ Cleveland State University \\ Cleveland, Ohio 44115 \\ J.A. DiCarlo \\ National Aeronautics and Space Administration \\ Glenn Research Center \\ Cleveland, Ohio 44135
}

\section{Summary}

Tensile strength, creep strength, and rupture strength properties were measured for the following types of polymer-derived stoichiometric SiC fibers: Hi-Nicalon Type S from Nippon Carbon, Tyranno SA from Ube, and Sylramic from Dow Corning. Also included in this study were an earlier version of the SA fiber plus two recent developmental versions of the Sylramic fiber. The tensile strength measurements were made at room temperature on as-received fibers and on fibers after high-temperature inert exposure. The creep-rupture property data were obtained at $1400^{\circ} \mathrm{C}$ in air as well as argon. Some fiber types showed strong effects of environment on their strength properties. These results are compared and discussed in terms of underlying mechanisms and implications for ceramic composites.

\section{Introduction}

Continuous silicon carhide fibers are being developed as reinforcement of ceramic matrix composites (CMC) for high temperature structural applications. Small diameter SiC fibers $(\sim 10$ to $14 \mu \mathrm{m})$ produced by polymer pyrolysis with little or no oxygen content display high stiffness, high room temperature strength, and improved thermal stability in comparison to other types of ceramic fibers. Recent examples of these lowoxygen types are the Hi-Nicalon fiber from Nippon Carbon (microcrystalline $\beta \mathrm{SiC}$ with $\sim 5 \mathrm{~nm}$ grain size plus excess carbon and trace oxygen) and the Sylramic fiber from Dow Corning (stoichiometric crystalline $\beta$-SiC with $\sim 100 \mathrm{~nm}$ grain size plus trace boron as a sintering additive). They have displayed improved creep and rupture properties compared to the first-generation oxygen-containing Nicalon SiC fiber (refs. 1 and 2 ). However, at temperatures above $\sim 1300{ }^{\circ} \mathrm{C}$, the nonstoichiometric Hi-Nicalon fiber displays weight loss, grain growth, and contraction. A drop in the fast fracture strength accompanies these phenomena, even though the creep strength of the fiber improved (refs. 3 and 4). In contrast, the Sylramic fiber showed no weight loss, grain growth, or contraction below $1500^{\circ} \mathrm{C}$. Thus the coarser grained stoichiometric Sylramic fiber is more thermally stable than the finer grained nonstoichiometric Hi-Nicalon fiber.

More recently, Nippon Carbon and Ube Industries have introduced their own stoichiometric SiC fibers, namely Hi-Nicalon Type $S$ and Tyranno SA, respectively, which have grain sizes and tensile strengths similar to those of the Sylramic fiber. These fiber types differ, however, in their production processes and in key details of their microstuctures. Improved tensile and creep-rupture strengths have also been achieved for the Sylramic fibers by special developmental processes which yield microstructures with smaller boron content and process-related flaws (ref. 6). The reduction in boron in the Sylramic grain boundaries improves the fiber creep strength; whereas the reduction in flaw size improves the fiber fast fracture strength. Thus there exists various process routes and microstructural possibilities for thermally stable stoichiometric SiC fibers.

The objective of this study is to determine key strength properties for a variety of stoichiometric SiC fibers that are currently available in continuous lengths. These properties include (1) fiber tensile strength before and after thermal exposure and (2) fiber creep strength and rupture strength at 1400 " $\mathrm{C}$ in air and in argon. These 
results along with other property data for the various fiber types are then compared and analyzed in order to obtain a hetter understanding of the current status of stoichiometric SiC fibers as reinforcement for high temperature CMC.

\section{Experimental Procedure}

Six types of stoichiometric SiC fibers were examined in this study. These include the most recent version of the Hi-Nicalon Type S fiber; an earlier and more recent version of the Tyranno SA fiber (SA(1) and SA(2)); the Sylramic fiber; and two recent types of developmental Sylramic fibers (Syl(1) and Syl(2)). The SA(1) fiber appears to be a finer grained version of the currently available SA fiber (called $S A(2)$ in this study). The Syl(1) and Syl(2) fibers were specially processed to reduce boron content (ref. 6). Typical properties of the fibers are listed in table 1 . To determine tensile strength, single fibers were tested to fracture at room temperature using a $25-\mathrm{mm}$ gauge length and a constant displacement rate of $1.27 \mathrm{~mm} / \mathrm{min}$. The creep-rupture properties were determined for single fibers at $1400^{\circ} \mathrm{C}$ using the same fiber creep-rupture facilities and procedures reported in detail elsewhere (refs. 7 and 8 ). Creep deformation versus time was recorded at a constant deadweight load using either 25 or $100 \mathrm{~mm}$ hot zone lengths for the air furnace and a $115 \mathrm{~mm}$ hot zone length for the argon furnace.

Auger electron spectroscopy (AES) depth-profile analysis and thermogravimetric analysis (TGA) were conducted on the different fiber types. For the TGA studies, weight change measurements were made in air and argon from room temperature to $1500{ }^{\circ} \mathrm{C}$. Also TEM analysis was used to evaluate grain size and chemistry in the cross sections of the fibers. AES and TEM were conducted on single fibers; while TGA was conducted on tows wrapped into small volumes with initial weights from $\sim 30$ to $50 \mathrm{mg}$.

\section{Results}

\section{Auger Electron Spectroscopy (AES)}

AES analyses were conducted at every $10 \mathrm{~nm}$ from the fiber surface to $\sim 300 \mathrm{~nm}$ deep. Figures 1 (a) to (c), show the chemical composition of the surface zone in the (a) Sylramic, (b) Syl(1), and (c) Syl(2) fiber types. The Sylramic fiber surface was enriched by carbon $\sim 10 \mathrm{~nm}$ deep. Beyond that, this fiber displayed a stoichiometric composition (nearly same $\mathrm{Si}$ and $\mathrm{C}$ atomic concentration). Boron existed in this Sylramic fiber up to at least $300 \mathrm{~nm}$ and noticeable amounts of boron and titanium were present on the fiber surface. The Syl(1) fiber (fig. 1(b)) showed a clear outer B-N rich layer which extended over $150 \mathrm{~nm}$ deep. This B-N rich area was not pure, but contained carbon and silicon with the first $\sim 70 \mathrm{~nm}$ deep zone being silicon-depleted. The amount of boron on the fiber surface correlates well with amount of free boron originally present in the bulk of the Sylramic fiber (refs. 6 and 10). The Syl(2) fiber (fig. 3(c)) showed a nearly pure C-rich zone formed from about $20 \mathrm{~nm}$ up to $\sim 100 \mathrm{~nm}$ deep. In comparison to the Sylramic fiber, the boron content below the surface of the Syl(2) fiber was reduced.

\section{TEM Microstructures}

TEM thin foils were prepared on fiber cross sections. Typical microstructures near the fiber surface zone are shown in figure 2 for (a) Sylramic, (b) Syl(1), and (c) SA(1). All fibers showed equiaxed and faulted $\beta-S i C$ grains with various sizes. The range of grain sizes for the Sylramic, Syl(1), and Syl(2) fibers were comparable, from $\sim 70$ to $\sim 170 \mathrm{~nm}$; while the grain sizes for the SA(1) and SA(2) fibers were mostly above $\sim 150$ and $\sim 200 \mathrm{~nm}$, respectively. Some grain junctions of the Sylramic and Syl(1) fibers were occupied by TiB2 and the frequency was higher for Sylramic than for Syl(1). This TiB2 phase was identified using both chemical elemental analysis and X-ray diffraction methods. The SA(1) fiber showed no second phase, even though aluminum compounds were reported to be utilized as sintering additives (ref. 9). 


\section{TGA Weight Change}

The change of initial weight of the $\mathrm{SiC}$ fiber tows was measured from room temperature up to $1500{ }^{\circ} \mathrm{C}$ at a warm-up rate of $\sim 5^{\circ} \mathrm{C} / \mathrm{min}$. The results for various types of $\mathrm{SiC}$ fibers are shown in figure $3(\mathrm{a})$ for air and in figure 3(b) for argon. Weight changes above 100 percent indicate a weight increase, and below 100 percent, a weight decrease. For the $\mathrm{SiC}$ fibers in general, weight increases above $500{ }^{\circ} \mathrm{C}$ can be related to the formation of silica and other impurity oxides on the fiber surfaces; while the decreases below $\sim 800^{\circ} \mathrm{C}$ are typically related to removal of the initial sizing or excess carbon from the fiber surfaces.

Figure 3 shows that TGA behavior was dependent on the individual fiber types, with measurable differences beginning near $\sim 250^{\circ} \mathrm{C}$. For example, the SA and Hi-Nicalon S fibers showed an abrupt weight decrease at $\sim 250{ }^{\circ} \mathrm{C}$, but the Sylramic fiber showed only a small decrease up to $\sim 450{ }^{\circ} \mathrm{C}$. This can be related to the amount of fiber sizing material; that is, less sizing for Sylramic and more sizing for SA and Hi-Nicalon $\mathrm{S}$. From $\sim 450{ }^{\circ} \mathrm{C}$ to $\sim 1000^{\circ} \mathrm{C}$, the Sylramic fiber showed weight gain up to $\sim 1.3$ percent in air and $\sim 0.4$ percent in argon; however, the Syl(1), SA(2), and Hi-Nicalon S fibers showed only $\sim 0.2$ to 0.5 percent increase in air and $<\sim 0.1$ percent increase in argon. (The weight gain in argon is believed to be due to trace oxygen in the argon.) The weight gain for the Sylramic fiber at intermediate temperatures in air and (impure) argon is probably due to the presence of boron and TiB2 on the fiber surface. That is, it is well known that liquid boria, which melts at $450^{\circ} \mathrm{C}$, can rapidly enhance silica growth on $\mathrm{SiC}$ materials (ref. 11). The developmental Syl $(1,2)$ fibers with reduced boron appear to measurably reduce this intermediate temperature effect. The large weight loss near $700{ }^{\circ} \mathrm{C}$ in air for the Syl(2) fiber can be attributed to its carbon-rich surface layer (see fig. 1(c)). Weight changes for the various fibers at intermediate temperatures are summarized in table II.

From 1000 to $1500{ }^{\circ} \mathrm{C}$ in argon (plus trace oxygen), most $\mathrm{SiC}$ fibers tested showed a continuous weight increase of $\sim 0.2$ percent; while the Sylramic reached a maximum then showed a weight decrease above $\sim 1200^{\circ} \mathrm{C}$. This drop might be attributed to the loss of horon from the borosilicate glass formed on the Sylramic fiber surface. In air near $1100{ }^{\circ} \mathrm{C}$, the rate of weight change showed a minimum for most fibers, but not for the Sylramic and $\operatorname{Syl}(1,2)$ fibers. Also up to $1500^{\circ} \mathrm{C}$, the total amount of weight gains for the $\mathrm{SA}(2)$ and Hi-Nicalon $S$ fibers were lower than for the three Sylramic fiber types. This enhanced oxidation might be attributed to the boron containing second phases that exist on the surfaces and in the bulk of the Sylramic fiber types.

\section{Tensile Strength}

The room-temperature tensile strengths are shown in figure 4 for the Hi-Nicalon S, SA(1,2), Sylramic, and Syl $(1,2)$ fibers after fabrication and after exposure at $1400{ }^{\circ} \mathrm{C}$ for $1 \mathrm{hr}$ in argon or at $1000^{\circ} \mathrm{C}$ for $3 \mathrm{hr}$ in vacuum. The strength values at each condition were the average of at least 12 single fibers removed from multifilament tows. Also shown are the standard deviations in strength. In general, the tensile strengths of the as-fabricated Sylramic, $\operatorname{Syl}(1,2)$, and SA(1) fibers were the highest, above $2800 \mathrm{MPa}$; while those of the asfabricated SA(2) and Hi-Nicalon S fibers were below $1800 \mathrm{MPa}$, particularly the SA(2) fiber which showed a low tensile strength of $\sim 1350 \mathrm{MPa}$. It should be noted that this as-fabricated strength for SA(2) is lower than that measured by the manufacturer (see table I), but is in qualitative agreement with the measured strength of SA(1) which is finer grained.

After exposure in vacuum or argon, the average tensile strength of the Sylramic fiber decreased by $\sim 15$ percent. A similar decrease was observed for the Hi-Nicalon $\mathrm{S}$ fiber after $1400{ }^{\circ} \mathrm{C}$ exposure. However. the Syl(1) fiber showed negligible tensile strength change after high-temperature exposure. These strength retention results are conflicting because most stoichiometric $\mathrm{SiC}$ fibers are reported to be stable after inert environmental exposures up to $1700^{\circ} \mathrm{C}$ (ref. 9). It may be possible that at intermediate temperatures from $1(0)()$ to $1400^{\circ} \mathrm{C}$, the fiber surface morphology was altered, giving rise to new surface flaws that could lower the tensile strength (ref. 12). Thus the impurity type and content on the surface of a given fiber type plus the chemical composition of the exposure environment may play important roles in the fiber's strength retention hehavior. 


\section{Creep Strength}

Typical creep curves are shown in figure 5 for the various stoichiometric $\mathrm{SiC}$ fibers at $1400{ }^{\circ} \mathrm{C}$ and $250 \mathrm{MPa}$ in air. The Sylramic, Syl(1,2), and Hi-Nicalon S fibers displayed a short transient primary creep stage followed by pseudo-steady state creep; while the SA(1,2) fiber showed a large transient stage with no significant pseudo-steady state creep. Figure 5 shows that under the given test conditions, the Syl( 1,2$)$ fibers are the most creep-resistant stoichiometric SiC fibers. The next most creep resistant fiber was the Hi-Nicalon $\mathrm{S}$. For prolonged times at $1400{ }^{\circ} \mathrm{C}$, the Sylramic fiber ruptured without any tertiary creep; while the Syl $(1,2)$ and $\mathrm{Hi}$-Nicalon $\mathrm{S}$ fibers did not rupture up to $100 \mathrm{hr}$. As expected from the grain size difference, a measurable improvement in creep behavior was observed for the $S A(2)$ fiber in comparison to the $S A(1)$ fiber. However, both fibers crept to above 1percent before rupturing. This amount of rupture strain appears to be abnormally large for a stoichiometric $\mathrm{SiC}$ fiber with a crystalline size of $>100 \mathrm{~nm}$.

The effect of stress on the $10 \mathrm{hr}$-creep strain at $1400^{\circ} \mathrm{C}$ for the stoichiometric SiC fibers is shown in figure 6 for (a) air and (b) argon test conditions. Also included in this plot for comparison is the Hi-Nicalon nonstoichiometric fiber (ref. 7). With increasing stress, the creep strain increased by a power dependence of $\sim 2$ for most $\mathrm{SiC}$ fibers both in air and argon (ref. 13). One exception is the Hi-Nicalon $\mathrm{S}$ fiber which indicated a lower stress dependency of $\sim 1$. For all stresses, 10-hr creep strain of the $\operatorname{Syl}(1,2)$ fibers was reduced by a factor of $\sim 10$ in comparison to the Sylramic fiber. Similarly the SA(2) fiber was more creep resistant than the SA(1) fiber by a factor of $\sim 3$. Creep resistance of the Hi-Nicalon $S$ fiber was between Sylramic and Syl $(1,2)$. The creep resistance of the $\operatorname{Syl}(1,2)$ fibers was comparable to that of a low-boron containing $\alpha$-SiC fiber with larger grain size (up to $2 \mu \mathrm{m}$ ) (ref. 7).

Figure 6 also shows that for the Sylramic, Syl(1), and Hi-Nicalon S fibers, the test environment had a significant effect on creep and creep strength. For these stoichiometric fibers at the same stress, the creep in argon was generally greater than in air. The creep strengths for 0.1 percent creep in $10 \mathrm{hr}$ at $1400{ }^{\circ} \mathrm{C}$ are summarized in table III. In air, creep strengths for the Sylramic, Hi-Nicalon S, and Syl(1) fibers were about 120,310 , and $520 \mathrm{MPa}$, respectively; while the strengths in argon were about $<50,210,230 \mathrm{MPa}$, respectively. The significant drop in creep resistance for the Syl(1) fiber in argon is not fully understood. This behavior can be contrasted with the creep strengths for the SA fibers and the nonstoichiometric Hi-Nicalon fiber (ref. 7) which showed no significant air/argon effect.

\section{Rupture Strength}

Results for rupture time versus stress at $1400^{\circ} \mathrm{C}$ are shown in figure 7 for the various fibers in (a) air and (b) argon. The Syl $(1,2)$ fibers were the most rupture resistant in air. Below $\sim 500 \mathrm{MPa}$, these fibers did not rupture; while the other fibers ruptured below $\sim 250 \mathrm{MPa}$. In air, the next most rupture-resistant fiber was $\mathrm{Hi}$-Nicalon S. Like creep strength, the Syl(1) fiber showed a lower rupture strength in argon than in air. In argon, the $\mathrm{SA}(1,2)$ and Hi-Nicalon $\mathrm{S}$ fibers exhibited higher rupture strength than the Sylramic and Syl(1) fibers. For the Sylramic, Syl(1), SA(2), and Hi-Nicalon S fibers, the $10 \mathrm{hr}$ rupture strengths in air were about $200,720,230,310 \mathrm{MPa}$; while those in argon were $<50,210,310$, and $280 \mathrm{MPa}$, respectively. The rupture strengths are summarized in table III. Generally for all fibers, the rupture strains in air were stress and time independent, but were about a factor of two larger in air than in argon. Apparently in the $1400{ }^{\circ} \mathrm{C}$ air environment, oxide formation blunted strength controlling flaws on the fiber surfaces; while in the argon environment, flaw blunting by silica formation was not available.

\section{Discussion}

Improvement in the fast fracture strength and long-term creep and rupture strengths of SiC fibers is desired for the successful application of structural CMC. Whereas these properties have been improved by the development of stoichiometric SiC fibers, further enhancement would be of benefit. This study has shown that one possible direction is by the use of improved processes for currently available fibers as, for example, those used to convert Sylramic to the developmental Syl(1,2), SA(1) to SA(2), and Hi-Nicalon to Hi-Nicalon S. 
Clearly the high temperature creep and rupture properties of these new fiber types are improved: but the fast fracture tensile strengths of some fiber types, such as the SA and Hi-Nicalon S are reduced by 20 to 40 percent. Currently it is believed that the enhanced creep-rupture properties for these new fibers are probably not all explained by the same mechanism. For example, based on a preliminary microstructural observations. the improvement of the creep and rupture strengths observed for Syl(1) was not directly related with an increase in grain size; while the $\mathrm{SA}(2)$ creep improvement can be related to an increase in grain size. On the other hand, the improvements observed for Hi-Nicalon S appear to be related to a variety of mechanisms: an increase in grain size, a reduction in oxygen impurity, and a restructuring of excess carbon (refs. 3 to 14). For the Sylramic fiber, which contains a small amount of boron sintering additives, it would appear that the creeprupture improvements seen for Syl(1,2) can be related to a reduction in the boron content along the grain boundaries. AES depth profiles (fig. 1) do indeed indicate boron depletion inside the fibers. A similar effect might be expected for the SA fibers if the aluminum sintering additives could be removed (ref. 9). However, although this may be possible by simple heat treatments, there is the possibility that new pores or flaws will be created plus the $\mathrm{SiC}$ toughness could decrease (ref. 15). In addition, as with the transition from SA(1) to $\mathrm{SA}(2)$, the fiber grains may grow, resulting in fibers with lower tensile strengths.

Currently it appears that there does not exist a certain fiber microstructure which will allow one type of stoichiometric SiC fiber to behave the best under all CMC application conditions. The Syl(1.2) fibers possess the best tensile strengths and the best creep strengths in air and argon. These fiber types also possess the best rupture strengths in air, but in argon the rupture strengths of the SA fibers are best. Also, the most creep resistant fibers, Syl $(1,2)$ and Hi-Nicalon S, display an air-argon environmental effect: that is, they creep more in argon. On the other hand, the more creep-prone SA(1,2) and Hi-Nicalon (ref. 7) fibers did not display a significant environment effect. For CMC applications, the results in argon might be considered representative of behavior of fibers embedded in an uncracked CMC; whereas the results in air are probably representative of the behavior of fibers in a cracked CMC exposed to an oxidizing environment. Clearly the fibers should be expected to experience a variety of CMC environments, ranging from inert to highly oxidizing. Thus, at the present time it is not clear which type of stoichiometric SiC fiber would be best for the majority of CMC applications. It is also unclear as to the mechanisms giving rise to the environmental effects observed for the some of the stoichiometric fibers of this study.

\section{Summary and Conclusions}

The stoichiometric SiC fibers evaluated in this study were found to display many similar properties that are beneficial for CMC fabrication and structural performance:

- Small diameter: 10-14 $\mu \mathrm{m}$. A good size for weaving and braiding multifilament tows into CMC fiber architectures.

- Grain size: $\sim 100 \mathrm{~nm}$. Probably maximum size for good as-produced fiber strength and good creep resistance.

- High modulus: $>380 \mathrm{GPa}$. Important for achieving high stress for $\mathrm{CMC}$ cracking.

- Tensile strength (as-produced and after thermal exposure): $>2$ GPa for all fibers except the SA(2) fiber of this study. Important for providing CMC graceful failure after CMC fabrication.

The stoichiometric SiC fibers, however, also displayed many dissimilar properties which must be examined further under actual CMC fabrication and application conditions in order to fully understand their impact on CMC performance:

- Thermal conductivity: SA $>$ Syl $(1,2)>\mathrm{Syl}>\mathrm{Hi}-\mathrm{Nic}-\mathrm{S}$. Important for reducing thermal stresses in high-temperature $\mathrm{CMC}$ applications.

- Surface roughness: not measured here hut differences are expected based on surface grain size. High roughness can increase CMC interfacial shear behavior. 
- Surface chemistry: Sylramic fibers with boron sintering additives display enhanced oxidation between 450 and $1000{ }^{\circ} \mathrm{C}$ due to boria formation. May result in enhanced fiber strength degradation and fiberfiber and fiber-matrix bonding in cracked CMC.

- Creep strength: depends on fiber environment and grain boundary phases introduced during fiber processing. Syl $(1,2)$ fibers with reduced boron sintering additives are best in air and argon; SA fibers with aluminum sintering additives are worst under same conditions. For creep-prone matrices, fiber creep controls CMC creep.

- Rupture strength: depends on fiber environment, creep resistance, and rupture strain. Creep-prone SA fibers rank highest because of relatively high rupture strains in air and argon. Fiber rupture directly controls CMC rupture life.

\section{References}

I. J.A. DiCarlo and S. Dutta: Continuous Ceramic Fibers for Ceramic Composites. HANDBOOK ON CONTINUOUS FIBER REINFORCED CERAMIC MATRIX COMPOSITES, eds. R.Lehman, S.ElRahaiby, and J.Wachtman, Jr., Ceramic Information Analysis Center, Purdue University, West Lafayette, Indiana, 1995, pp. 137-183.

2. K. Okamura, "Ceramic Fibers from Polymer Precursors," Composites, 18, 2, 1987, pp. 107-120.

3. R. Bodet, X. Bourrat, J. Lamon, and R. Naslain, "Tensile Creep Behavior of a Silicon Carbide-Based Fiber with a Low Oxygen Content," J. of Materials Sci., 30, 1995, pp. 661-677.

4. H.M. Yun and J.A. DiCarlo, "High Temperature Contraction Behavior of Polymer-Derived SiC Fibers," Cer. Eng. and Sci. Proceedings, 18A, 1997, pp. 135-146.

5. J. Lipowitz, J.A. Rabe, L.K. Frevel, and R.L. Miller, "Characterization Of Nanoporosity In PolymerDerived Ceramic Fibers By X-Ray Scattering Techniques," J. of Mat. Sci., 25, 1990, pp. 2118-2124.

6. H.M. Yun and J.A. DiCarlo, unpublished work, 1997.

7. H.M. Yun, J.C. Goldsby, and J.A. DiCarlo, "Environmental Effects on Creep and Stress-Rupture Properties of Advanced SiC Fibers," "High-Temperature Ceramic-Matrix Composites II: Manufacturing and Materials Development," eds. A.G. Evans and R. Naslain, Ceramic Transactions, Vol. 58, 1995, pp. $331-336$.

8. H.M. Yun, J.C. Goldsby, and J.A. DiCarlo, "Tensile Creep and Stress - Rupture Behavior of Polymer Derived SiC Fibers," NASA TM-106692, 1994.

9. J.A. DiCarlo, H.M. Yun, and J.C. Goldsby, "Creep and Rupture Behavior of Advanced SiC Fibers," Proc. ICCM-10, Whistler, B.C, Canada, August, 1995, VI, pp. 315-322.

10. K. Kumagawa, H. Yamaoka, M. Shibuya, and T. Yamamura, "Fabrication and Mechanical Properties of New Improved Si-M-C-(O) Tyranno Fiber," Cer. Eng. and Sci. Proceedings, 19A, 1998; pp. 65-72.

11. L. Lipowitz, R.A. Rabe, A. Zangvil, and Y. Xu, "Structure and Properties of Sylramic ${ }^{\mathrm{TM}}$ Silicon Carbide Fiber - A Polycrystalline, Stoichiometric $\beta$ SiC Composition," Cer. Eng. and Sci. Proceedings, 18A, 1997.

12. J. Schlichting, "Oxygen Transport through Glass Layers Formed by a GEL Process," J. of Non-Crystalline Soilds, vol. 63, 1984, pp. 173-181.

13. F. Rebillat, A. Guette, L. Espitalier, and R. Naslain, "Chemical and Mechanical Degradation of Hi-Nicalon and Hi-Nicalon S Fibers under CVD/CVI BN Processing Conditions," HIGH TEMPERATURE CERAMIC MATRIC COMPOSITES III, The Ceramic Society of Japan, 1998, pp. 31-34.

14. J.A. DiCarlo and H.M. Yun, "Microstructural Factors Affecting Creep-Rupture Failure of Ceramic Fibers and Composites," Ceramic Transactions, 99, 1998, pp. 119-134.

15. M. Takeda, J. Sakamoto, Y. Imai, H. Ishikawa, and T. Ishikawa, "Properties of Stoichiometric Silicon Carbide Fiber Derived from Polycarbosilane," Cer. Eng. and Sci. Proceedings, 15, 1994, pp. 133-141.

16. M.E. Sixta, W.J. MoberlyChan, and L.C. De Jonghe, "Grain boundaries, Oxidation, and Strength of Heat Treated SiC," Cer. Eng. and Sci. Proceedings, 19A. 1998, pp. 509-516. 
TABLE I.-NOMINAL PROPERTIFS OF NEAR STOICHIOMETRIC $\beta$ SiC FIBERS

(Currently available in continuous lengths)

\begin{tabular}{|c|c|c|c|c|c|c|}
\hline Trade name & Hi-Nicalon S & SA(I) & $\mathrm{SA}(2)$ & Sylramic & $\begin{array}{l}\text { Syl. (1) } \\
\text { Devel. }\end{array}$ & $\begin{array}{l}\text { Syl. (2) } \\
\text { Devel. }\end{array}$ \\
\hline Manufacturer & $\begin{array}{l}\text { Nippon } \\
\text { carbon }\end{array}$ & $\begin{array}{c}\text { Uhe } \\
\text { Industries }\end{array}$ & $\begin{array}{c}\text { Uhe } \\
\text { industries }\end{array}$ & $\begin{array}{l}\text { Dow } \\
\text { Corning } \\
\end{array}$ & $\begin{array}{c}\text { Dow } \\
\text { Corning } \\
\end{array}$ & $\begin{array}{c}\text { Dow } \\
\text { Corning } \\
\end{array}$ \\
\hline $\begin{array}{l}\text { Process. (Sintering } \\
\mathrm{T} .>1600 \mathrm{C} \text { ) }\end{array}$ & \begin{tabular}{|c|}
$\begin{array}{c}\text { Polymer D. } \\
\text { Sintering } \\
\end{array}$ \\
\end{tabular} & $\begin{array}{l}\text { Polymer D./ } \\
\text { Sintering }\end{array}$ & $\begin{array}{l}\text { Polymer D./ } \\
\text { Sintering }\end{array}$ & $\begin{array}{l}\text { Polymer D./ } \\
\text { Sintering }\end{array}$ & $\begin{array}{l}\text { Polymer D./ } \\
\text { Sintering }\end{array}$ & $\begin{array}{c}\text { Polymer D. } \\
\text { Sintering }\end{array}$ \\
\hline Average grain size. ${ }^{*} \mathrm{~nm}$ & $22(\mathrm{XRD})$ & -150 & $>\sim 150$ & $\sim 100$ & -100 & -100 \\
\hline $\begin{array}{l}\text { Second phases or impurity } \\
\text { conc. (wt.\%) }\end{array}$ & $0(0.2)$ & $\begin{array}{l}\text { Al }(<2) \\
O(0.3)\end{array}$ & $\begin{array}{l}A \mathrm{Al}(<2) . \\
O(0.3)\end{array}$ & $\mathrm{TiB}_{2}, \mathrm{~B}$ & $\begin{array}{c}\text { Reduced } \mathrm{B} \text {. } \\
\mathrm{TiB}, \mathrm{B}-\mathrm{N}\end{array}$ & $\begin{array}{c}\text { Reduced B. } \\
\text { TiB..C }\end{array}$ \\
\hline Density, $\mathrm{g} / \mathrm{cm}^{3}$ & 3.0 & 3.02 & 3.1 & 3.1 & $>3.1$ & $>3.1$ \\
\hline Average diameter, $\mathrm{mm}$ & 13 & 10 & 10 & 10 & 10 & 10 \\
\hline Number of filaments & $5(00)$ & 800 & 800 & 800 & 800 & 800 \\
\hline PVA sizing. wt. $\%$ & 12 & $(-1.0)^{n}$ & $(\sim 1.0)^{\mathrm{n}}$ & $\sim 0.2$ & ----- & $\ldots \ldots$ \\
\hline Modulus at RT (GPa) & $400-420$ & 306 & 375 & -400 & $>400$ & $>400$ \\
\hline Tensile strength. MPa & $\sim 2500$ & $27(0)$ & 2800 & 3200 & -3200 & -3200 \\
\hline Tensile elongation, percent & -0.6 & -0.9 & $\sim 0.7$ & $\sim 0.8$ & $<-0.8$ & $<-0.8$ \\
\hline Thermal cond. $\left(\mathrm{W} / \mathrm{m}^{2} \mathrm{C}\right)$ & 18.4 & $--\cdots$ & 64.6 & 46.0 & $>46$ & $>46$ \\
\hline
\end{tabular}

"Measured on TEM microstructures

'PEO sizing.

"At room temperature.

TABLE II.-WEIGHT GAIN OF VARIOUS SiC TOWS AT INTERMEDIATE TEMPERATURES

\begin{tabular}{|l|c|c|c|c|c|}
\hline \multirow{2}{*}{ Fiber type } & \multirow{2}{*}{$\begin{array}{c}\text { Sizing } \\
\text { material }\end{array}$} & \multicolumn{2}{|c|}{ Test conditions, temperatures. } & \multicolumn{2}{c|}{$\begin{array}{c}\text { Weight gain. } \\
\text { percent . }\end{array}$} \\
\cline { 3 - 6 } & & Air & Argon & Air & Argon \\
\hline SYLRAMIC & PVA & 320 to 1000 & 500 to $1000(1210)$ & 1.28 & $0.43(0.63)$ \\
\hline SYL.(2) & & 460 to 1000 & & -0.73 & \\
\hline SYL.(1) & & $5001010(0)$ & 500 to 1000 & 0.24 & -0.04 \\
\hline Hi-NIC. S & PVA & 430 to 980 & 460 & 0.18 & 0.05 \\
\hline SA(2) & PEO & 470 to $100(0)$ & 440 to 1000 & 0.26 & 0.03 \\
\hline
\end{tabular}

"Determined by TGA

"Argon contains trace oxygen.

TABLE III-STRENGTH PROPERTIES OF AS-RECEIVED AND TREATED SYLRAMIC FIBERS

\begin{tabular}{|l|c|c|c|c|c|c|}
\hline \multicolumn{1}{|c|}{ Fiber type } & & Sylramic & Syl. (1) & Syl. (2) & SA (2) & $\begin{array}{c}\text { Hi-NiC. } \\
\text { Type S }\end{array}$ \\
\cline { 3 - 6 } & & $\begin{array}{c}\text { Creep-rupture } \\
\text { strength at } \\
1400^{\circ} \mathrm{C} . \\
\mathrm{MPa}\end{array}$ & & & \\
\hline $\begin{array}{l}10 \mathrm{hr} / 0.1 \text { percent } \\
\text { creep }\end{array}$ & Air & 120 & 520 & 510 & 115 & 310 \\
\hline $10 \mathrm{hr}$-rupture & Air & 200 & 720 & 700 & 230 & 310 \\
\hline $\begin{array}{l}10 \mathrm{hr} / 0.1 \text { percent } \\
\text { creep }\end{array}$ & Argon & $<50$ & 230 & --- & 110 & 210 \\
\hline $10 \mathrm{hr}$-rupture & Argon & $<50$ & 210 & --- & 310 & 280 \\
\hline
\end{tabular}




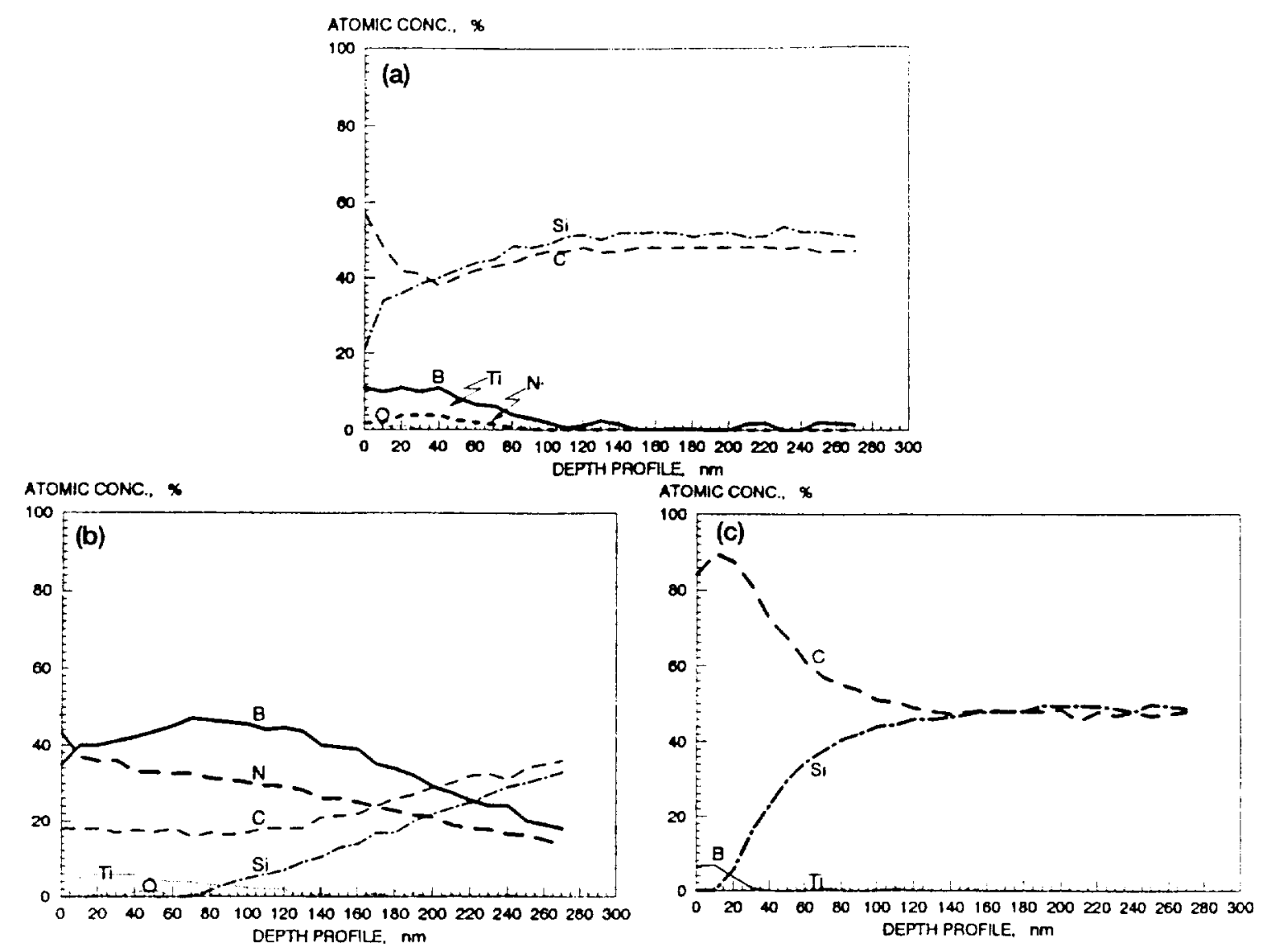

Figure 1.-AES depth profile of surface of Sylramic SiC fiber types, (a) Sylramic, (b) Syl. (1), and (c) Syl. (2).

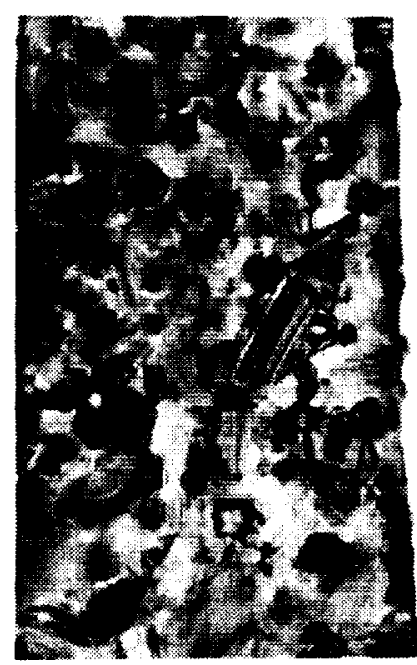

SYLRAMIC

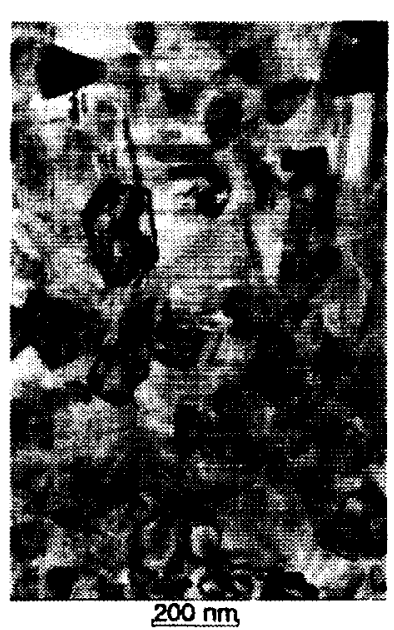

SYL.(1)

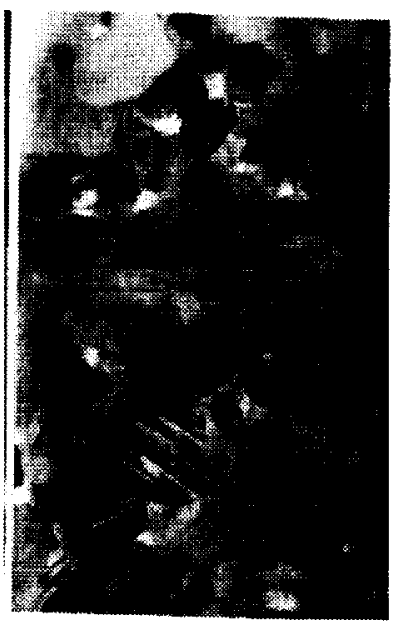

SA(1)

Figure 2.-TEM microstructures of SiC fibers, fiber cross-sections. 

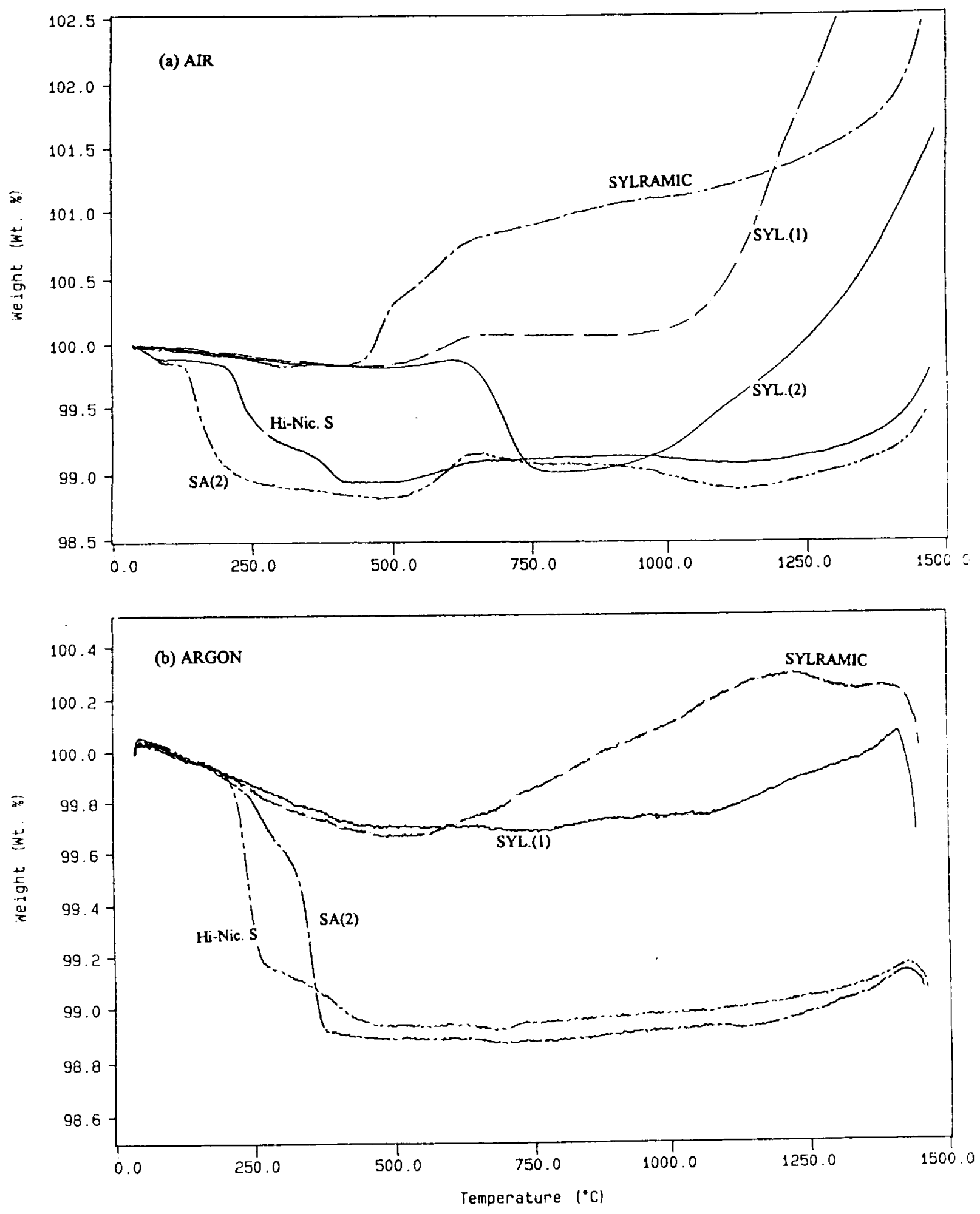

Figure 3.-TGA weight change of sized SiC fibers (a) in dry air and (b) in argon. Warm-up rate $-5^{\circ} \mathrm{C} / \mathrm{min}$. 
STRENGTH, KSI

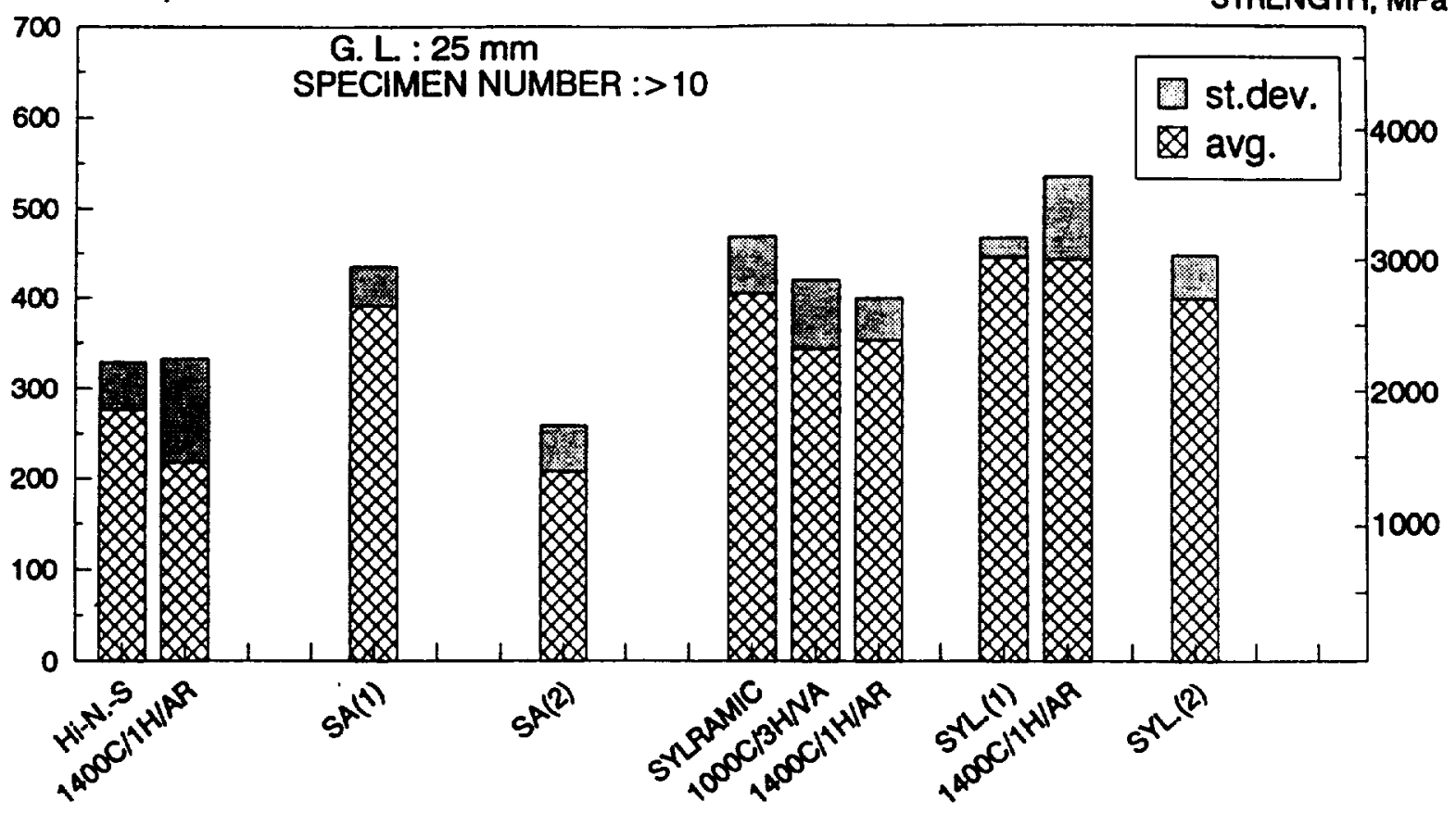

SiC FIBER TYPES

Figure 4.-Room temperature tensile strength of $\mathrm{SiC}$ fibers: as-received and after exposure in inert environments.

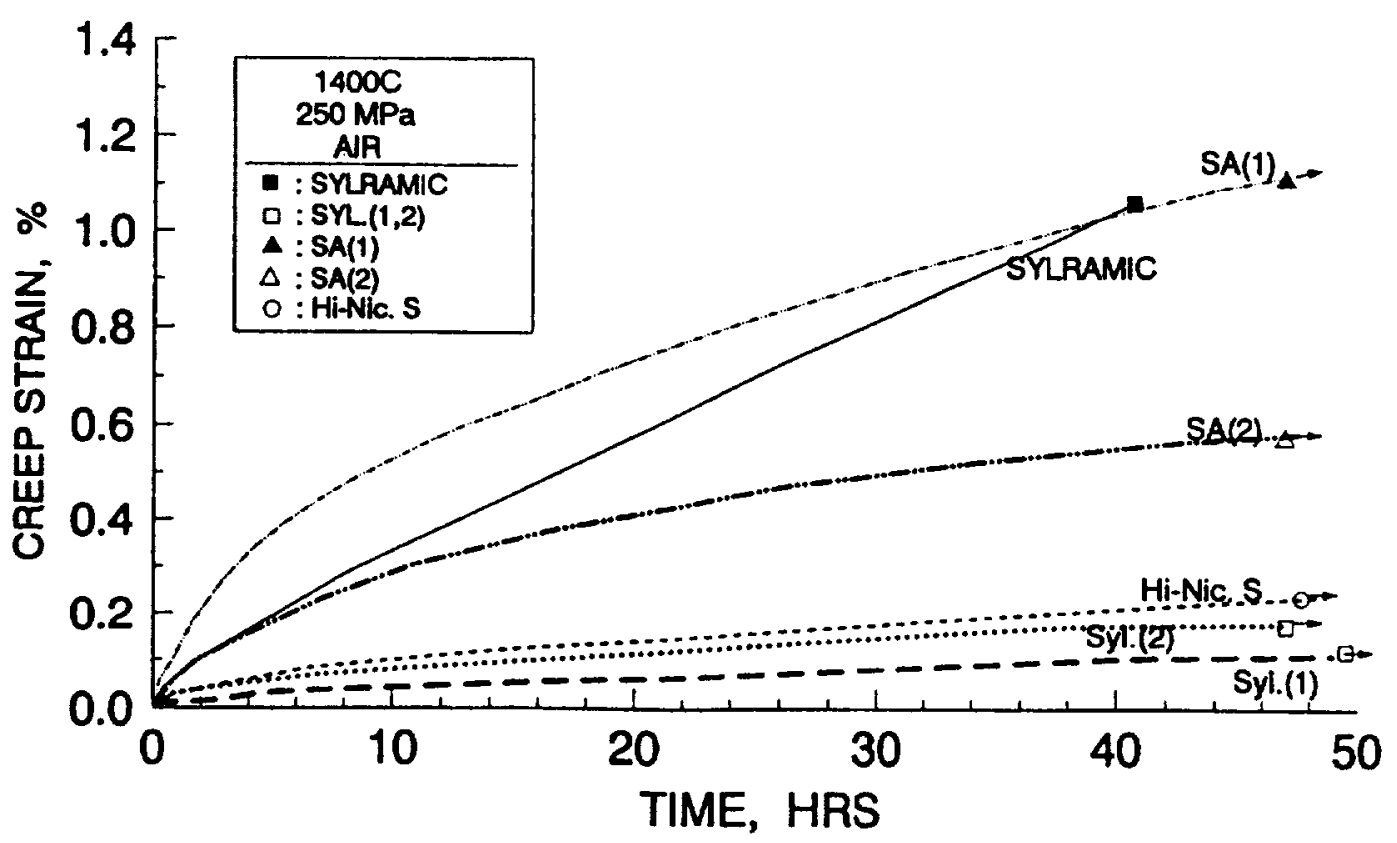

Figure 5.-Typical creep-rupture curves for various stoichiometric SiC fibers. 

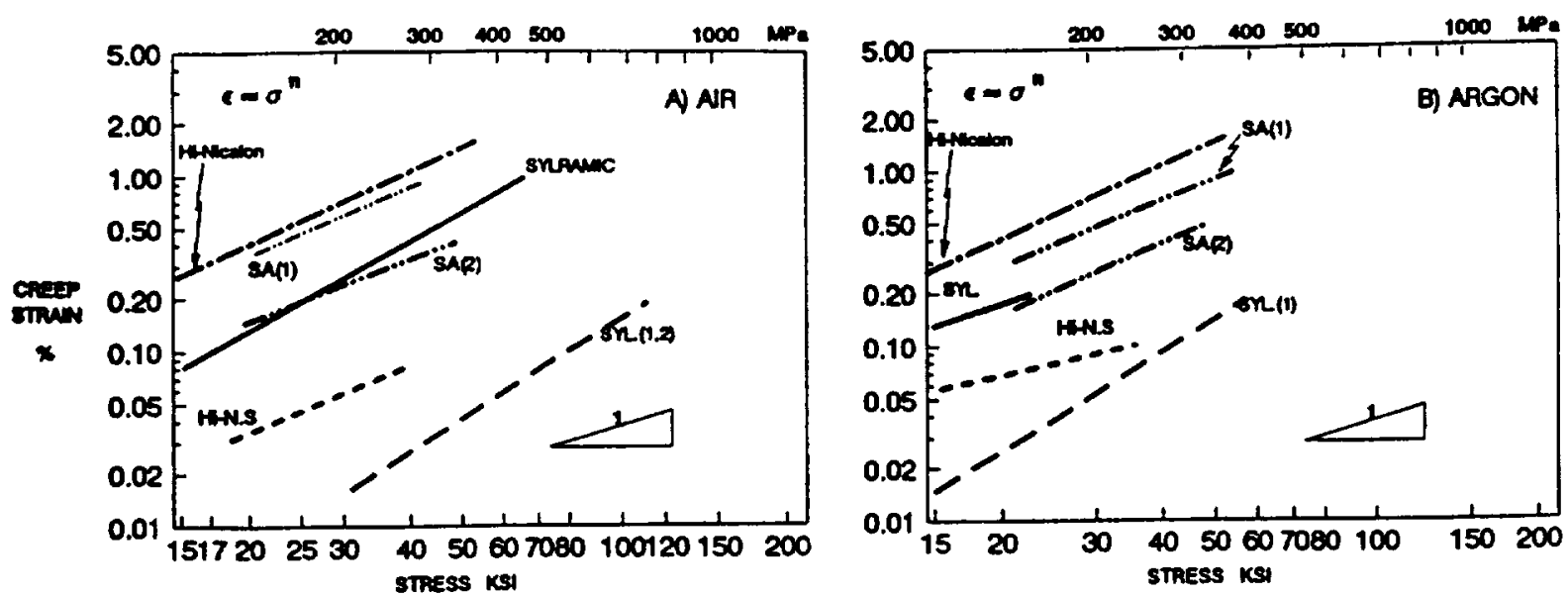

Figure 6.-Stress-effects on creep strain of $\mathrm{SiC}$ fibers at 10 hour and $1400^{\circ} \mathrm{C}$ : (a) in air and (b) in agron.
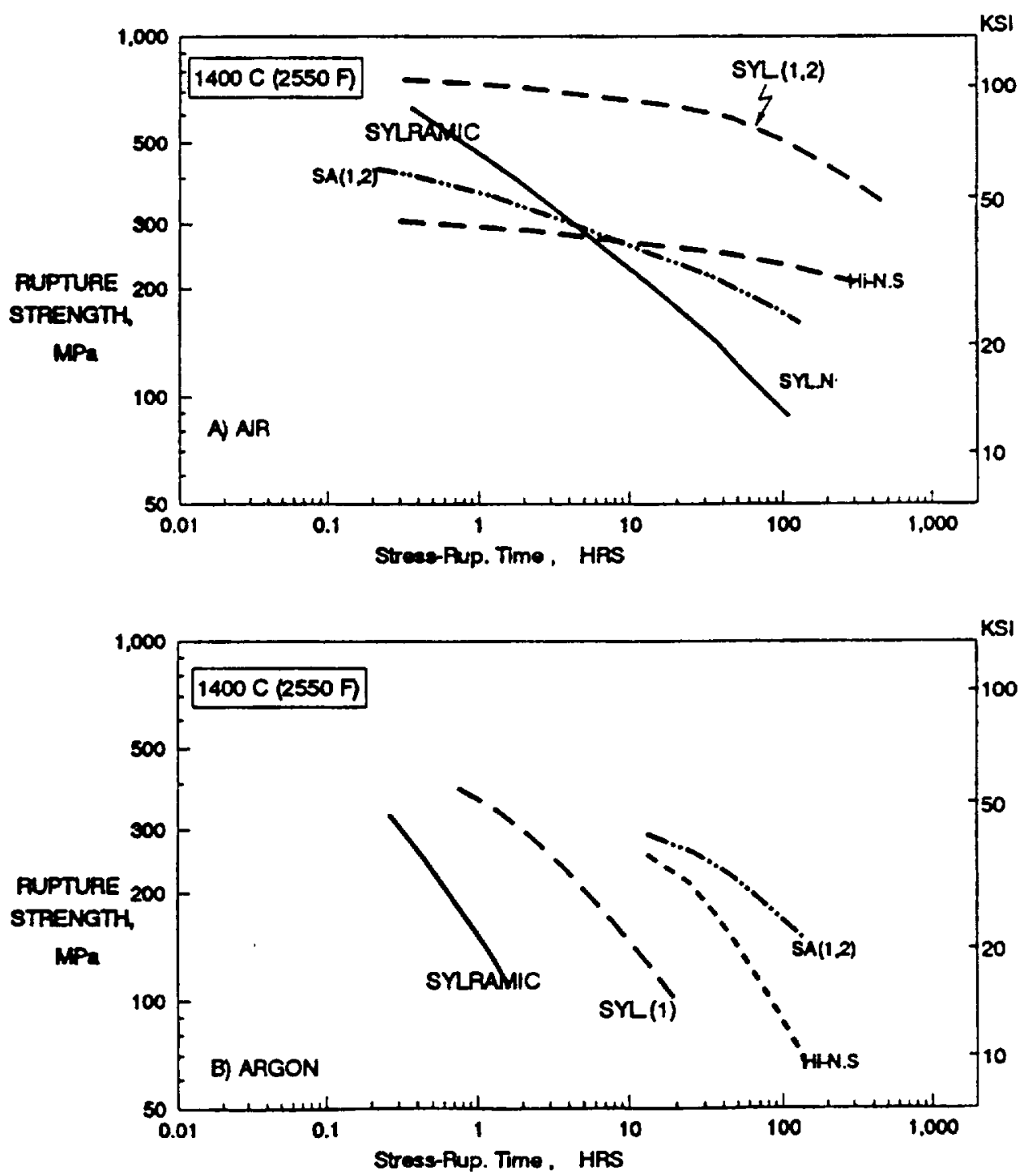

Figure 7.-Rupture strengths of $\mathrm{SiC}$ fibers at $1400^{\circ} \mathrm{C}$ : (a) in air and (b) in agron. 
Public reporting burden for this coliection of information is estimated to average 1 hour per response, including the time for reviewing instructions, searching existing data sources, gathering and maintaining the data needed, and completing and reviewing the collection of information. Send comments regarding this burden estimate or any other aspect of this collection of information, including suggestions for reducing this burden, to Washington Headquarters Services. Directorate for Information Operations and Reports, 1215 Jefferson Davis Highway, Suite 1204. Artington, VA 22202-4302, and to the Office of Management and Budget, Paperwork Reduction Project (0704-0188), Washington, DC 20503.

\begin{tabular}{|l|l|l}
\hline 1. AGENCY USE ONLY (Leave blank) & $\begin{array}{c}\text { 2. REPORT DATE } \\
\text { July } 1999\end{array}$ & $\begin{array}{r}\text { 3. REPORT TYPE AND DATES COVERED } \\
\text { Technical Memorandum }\end{array}$
\end{tabular}

\section{TITLE AND SUBTITLE}

Comparison of the Tensile, Creep, and Rupture Strength Properties of Stoichiometric SiC Fibers

\section{AUTHOR(S)}

H.M. Yun and J.A. DiCarlo

\section{PERFORMING ORGANIZATION NAME(S) AND ADDRESS(ES)}

National Aeronautics and Space Administration

John H. Glenn Research Center at Lewis Field

Cleveland, Ohio 44135-3191
5. FUNDING NUMBERS

WU-537-04-20-00

\section{SPONSORING/MONITORING AGENCY NAME(S) AND ADDRESS(ES)}

National Aeronautics and Space Administration

Washington, DC 20546-0001
8. PERFORMING ORGANIZATION REPORT NUMBER

$E-11753$

\section{SUPPLEMENTARY NOTES}

Prepared for the 23rd Annual Cocoa Beach Conference sponsored by the American Ceramic Society, Cocoa Bcalch. Florida, January 25-29, 1999. H.M. Yun, Cleveland State University, Cleveland, Ohio 441 15, and J.A. DiCarlı. N.IS I Glenn Research Center. Responsible person, J.A. DiCarlo, organization code 5130, (216) 433-5514.

12a. DISTRIBUTION/AVAILABILITY STATEMENT

Unclassified - Unlimited

Subject Categories: 24, 27
Distribution: Nonstandard

This publication is available from the NASA Center for AeroSpace Information, (301) 621-0390.

\section{ABSTRACT (Maximum 200 words)}

Tensile strength, creep strength, and rupture strength properties were measured for the following types of polymirderived stoichiometric SiC fibers: Hi-Nicalon Type S from Nippon Carbon, Tyranno SA from Ube, and Sylranic lrum Dow Corning. Also included in this study were an earlier version of the SA fiber plus two recent developmental is of the Sylramic fiber. The tensile strength measurements were made at room temperature on as-received fibers ancl in fibers after high-temperature inert exposure. The creep-rupture property data were obtained at 1400 " $\mathrm{C}$ in air as well is argon. Some fiber types showed strong effects of environment on their strength properties. These results are comparcil and discussed in terms of underlying mechanisms and implications for ceramic composites.

\begin{tabular}{|c|c|c|}
\hline \multicolumn{3}{|c|}{$\begin{array}{l}\text { 14. SUBJECT TERMS } \\
\text { SiC fiber; SiC stoichiometry; Tensile strength; Creep/rupture strength; } \\
\text { AES depth profiles }\end{array}$} \\
\hline $\begin{array}{l}\text { 17. SECURITY CLASSIFICATION } \\
\text { OF REPORT } \\
\text { Unclassified }\end{array}$ & $\begin{array}{l}\text { 18. SECURITY CLASSIFICATION } \\
\text { OF THIS PAGE } \\
\text { Unclassified }\end{array}$ & $\begin{array}{l}\text { 19. SECURITY CLASSIFICATION } \\
\text { OF ABSTRACT } \\
\text { Unclassified }\end{array}$ \\
\hline
\end{tabular}


